\title{
Study of seawater biofiltration by measuring adenosine triphosphate (ATP) and turbidity
}

\author{
$\underline{\text { F. Xavier Simon }}^{1 *}$, Elisabet Rudé ${ }^{1}$, Joan Llorens ${ }^{1}$, Sylvie Baig ${ }^{2}$ \\ ${ }^{1}$ Department of Chemical Engineering, University of Barcelona, C/ Martí i Franquès 1, 08028 \\ Barcelona, Spain \\ ${ }^{2}$ Degrémont SA, 183 avenue du 18 juin 1940, 92508 Rueil-Malmaison cedex, France
}

\begin{abstract}
In the present study, we examined seawater biofiltration in terms of adenosine triphosphate (ATP) and turbidity. A pilot biofilter continuously fed with fresh seawater reduced both turbidity and biological activity measured by ATP. Experiments operated with an empty bed contact time (EBCT) of between 2 and 14 min resulted in cellular ATP removals of $32 \%$ to $60 \%$ and turbidity removals of $38 \%$ to $75 \%$. Analysis of the water from backwashing the biofilter revealed that the first half of the biofilter concentrated around $80 \%$ of the active biomass and colloidal material that produces turbidity. By reducing the EBCT, the biological activity moved from the first part of the biofilter to the end. Balances of cellular ATP and turbidity between consecutive backwashings indicated that the biological activity generated in the biofilter represented more than $90 \%$ of the detached cellular ATP. In contrast, the trapped ATP was less than $10 \%$ of the overall cellular ATP detached during the backwashing process. Furthermore, the biological activity generated in the biofilter seemed to be more dependent on the elapsed time than the volume filtered. In contrast, the turbidity trapped in the biofilter was proportional to the volume filtered, although a slightly higher amount of turbidity was found in the backwashing water; this was probably due to attrition of the bed medium. Finally, no correlations were found between turbidity and ATP, indicating that the two parameters focus on different matter. This suggests that turbidity should not be used as an alternative to cellular concentration.
\end{abstract}

Keywords: biofilter; biofiltration; seawater; adenosine triphosphate (ATP); turbidity

* To whom correspondence should be addressed.

E-mail: xsimon@ub.edu

Tel: +34 934020155; Fax: +34934021291 


\section{Introduction}

Increasing water demand has led to the development of new strategies for using existing water resources. At the same time, technological developments have improved water treatment processes to guarantee and maximize the production of high-quality water for different purposes. From a general point of view, biofiltration uses living material to capture and biologically degrade pollutants. The biofiltration of surface water is a common operation that has been widely and successfully used in water treatment for the last 20 years (Huck et al., 1994; Urfer et al., 1997). Biofiltration is used as a pretreatment process in membrane filtration (Persson et al., 2006; Chinu et al., 2009) and is installed downstream from advanced oxidation processes (e.g. ozonation) to reduce ozonation by-products (Servais et al., 1994; Carlson and Amy, 1997; Ahmad and Amirtharajah, 1998). Another purpose of biofiltration is consumption of the biodegradable fraction of natural organic matter (NOM) in order to prevent downstream operational problems such as regrowth in pipelines (Servais et al., 1994; Huck et al., 1994; Urfer et al., 1997; Ahmad et al., 1998; Ahmad and Amirtharajah, 1998; Persson et al., 2006; Emelko et al., 2006). Furthermore, good efficiency in turbidity removal can also be attributed to biofiltration since it can act as a conventional physical filter, which results in acceptable filtration performances (Wang et al., 1995; Urfer et al., 1997; Ahmad and Amirtharajah, 1998; Emelko et al., 2006).

Biofilters consist of a packed bed, which can be made of different porous materials, with an attached biomass that forms a biofilm on the surface (Huck et al., 1994). The filter medium provides the surface for cell attachment (Wang et al., 1995). Attached growth has several advantages over suspended growth, and some of these were reviewed by Cohen (2001). In a biofilter, the biomass grows at the expense of the biodegradable matter present in the medium, leaving depleted water downstream with only the more refractory substances that should not interfere in subsequent processes. Assuming that temperature is barely controlled in industrialized biofilters, the process variables in biofilters are commonly the empty bed contact time (EBCT), the hydraulic loading rate (HLR) and the intensity and frequency of the backwashings (BW) (Liu et al., 2001; Miltner et al., 1995; Urfer et al., 1997; Persson et al., 2006). Periodic backwashings of the bed are necessary in order to maintain the performance of the biofilter by removing the biomass that has built up and the captured suspended 
solids (Ahmad and Amirtharajah, 1998). Different types of filter media have been used, e.g. granulated activated carbon (GAC), expanded clay (EC).

Many studies of freshwater biofiltration can be found in the literature; unfortunately, to the best of our knowledge few papers concerning seawater biofiltration are available. A summary of seawater biofiltration studies found in the literature are shown in Table 1. Note that, despite anthracite and sand in slow-filtration mode could also be considered biofilters (Wang et al., 1995) they are not taken into account.

\section{Table 1}

In this work, we study biofiltration as a process for reducing colloidal matter and the biological activity of seawater. For this purpose, different EBCTs, between 14 and 2 min, corresponding to hydraulic loading rates between 6 and $25 \mathrm{~m} \mathrm{~h}^{-1}$, were tested in a pilot-scale biofilter. The biological activity was evaluated by measuring adenosine triphosphate (ATP) and the colloidal material by measuring turbidity. The biological activity and colloids trapped, accumulated and generated during the continuous biofiltration operation were considered.

\section{Materials and methods}

\subsection{Pilot biofilter}

A pilot biofilter was installed and operated on the coast of Barcelona, next to the Barcelona city desalination plant in El Prat de Llobregat. The pilot plant was operated for one year. The biofilter consisted of two glass columns filled with expanded clay as a filter medium (columns C-1 and C-2) (see Figure 1). Both columns were connected and operated in series. Teflon ${ }^{\circledR}$ tubing was used for all streams: inlet, outlet and interconnections. In order to avoid algal growth, the columns were wrapped in aluminium foil.

Three sample points were analysed: the seawater inlet (inlet), the outlet of column C-1 (outlet C-1) and the outlet of column C-2 (outlet C-2). Note that the outlet of C-2 is also referred to as the biofilter effluent. Figure 1 shows a schematic representation of the pilot biofilter and $\quad$ Table gives the characteristics of the packed bed.

Particles of expanded clay, Biolite ${ }^{\circledR}$ L2.7, were used as a packing medium in the biofilter. This porous material has a high specific area and provides a surface for the biomass to attach to and grow on. 
Seawater was pumped directly from the NW Mediterranean Sea, $2 \mathrm{~km}$ offshore and at a depth of $25 \mathrm{~m}$. Table 3 summarizes the seawater characteristics.

\section{Table 3}

More details on seawater characterization and analyses are given elsewhere (Simon et al., 2011; Simon et al., 2013; Penru et al., 2013).

\section{Biomass acclimation}

The colonization and acclimation of the biofilter was performed by filtration of seawater for several months. An additional biodegradable source of carbon, e.g. sodium acetate or glucose, was not supplied, as proposed by other authors (Yang et al., 2001; Visvanathan et al., 2003; Meesters et al., 2003). During the acclimatization period, dissolved oxygen was measured in the inlet and outlet streams in order to ensure a steady-state regime prior to the normal biofiltration operation.

\section{Backwashing}

Both columns were backwashed separately twice a week. The backwashing process involved water washing and air scouring (Amirtharajah, 1993; Ahmad and Amirtharajah, 1998; Emelko et al., 2006). During the backwashing process, the bed expanded by up to $20-30 \%$. Raw seawater was used as a washing medium and carrier for the detached biomass, as proposed by other authors (Liu et al., 2001).

ATP and turbidity samples (referred as $S_{1}-S_{3}$ ) were collected during the backwashing protocol described below:

1. Partial drainage of the water in the column

2. Bed expansion with air $\left(100 \mathrm{~m} \mathrm{~h}^{-1}\right.$ for $\left.1 \mathrm{~min}\right)$

3. Water and air washing (water $20 \mathrm{~m} \mathrm{~h}^{-1} \mid$ air $100 \mathrm{~m} \mathrm{~h}^{-1}$ for $3 \mathrm{~min}$ ), $\rightarrow S_{l}$

4. Water washing only $\left(20 \mathrm{~m} \mathrm{~h}^{-1}\right.$ for $\left.2 \mathrm{~min}\right)$

5. Repeat 1-4 $\rightarrow S_{2}$ (during water and air washing sampling)

6. Final rinsing $\left(20 \mathrm{~m} \mathrm{~h}^{-1}\right.$ for $\left.12 \mathrm{~min}\right) \rightarrow S_{3}$ 


\subsection{Experimental conditions}

Different operational conditions were analysed. The EBCT varied from 14 to $1.8 \mathrm{~min}$, which corresponded to hydraulic rates from 6 to $25 \mathrm{~m} \mathrm{~h}^{-1}$. Table 4 summarizes the experimental conditions.

\section{Table 4}

\subsection{Analytical determinations}

All materials used in the analyses were made of glass or Teflon ${ }^{\circledR}$. These materials were carefully cleaned before use in order to avoid contamination. Glass material was first soaked in $\mathrm{HCl}$ aqueous solution $(10 \% \mathrm{~V} / \mathrm{V})$ for 24 hours and then rinsed with large amounts of Milli-Q water. After this, the material was covered with aluminium foil and muffled at $450^{\circ} \mathrm{C}$ for 4 hours to remove all remaining traces of organic compounds. Plastic material was also cleaned and sterilized by autoclave (QM 4000 SA-202X, Quirumed Spain) for $30 \mathrm{~min}$ at $121^{\circ} \mathrm{C}$.

\section{Adenosine triphosphate (ATP) determination}

ATP measurements were performed to monitor the biomass activity in the seawater samples during the biofiltration process, but also in the backwashing samples. ATP $\left(\mathrm{ATP}_{\mathrm{TOTAL}}\right)$ is present in the ecosystem in two forms: cellular ATP $\left(\mathrm{ATP}_{\mathrm{CELL}}\right)$, which is directly associated with living cells, and free ATP $\left(\mathrm{ATP}_{\mathrm{FREE}}\right)$ dissolved in the media and not contained in the cells, known as extracellular ATP (Karl, 1980). The ATP CELL $_{\text {. }}$ content is proposed as an indicator of active biomass content, since ATP is a biomolecule present in all active microorganisms (Holm-Hansen and Booth, 1966; Hammes et al., 2010). In this work ATP CELL content was chosen instead of heterotrophic plate count (HPC) for measuring active biomass content. Although HPC and ATP sometimes correlate (Deininger and Lee, 2001; Delahaye et al., 2003; Magic Knezev and van der Kooij, 2004; Hammes et al., 2010), especially in water with a low organic content (Veza et al., 2008), using HPC everestimates underestimates the real content of cells because it measures cultivable cells (Ahmad and Amirtharajah, 1998). In addition, ATP analysis is less laborious and time-consuming than other methods of assessing biomass (Velten et al., 2007). 
ATP $_{\text {TOTAL }}$ and ATP $_{\text {FREE }}$ were quantified using a BacTiter-Glo ${ }^{\mathrm{TM}}$ Microbial Cell Viability Assay (G8231, Promega Biotech Ibérica, Spain) and a GloMax ${ }^{\circledR}$ 20/20 Luminometer (Promega Biotech Ibérica, Spain). Samples were previously filtered through a $0.22-\mu \mathrm{m}$ filter (to retain bacterial cells) to measure ATP $\mathrm{FREE}_{\text {. The ATP }} \mathrm{CELL}_{\mathrm{C}}$ was determined indirectly by subtracting the $\mathrm{ATP}_{\mathrm{FREE}}$ from the $\mathrm{ATP}_{\mathrm{TOTAL}}$, as described by Equation 1:

$$
A T P_{C E L L}=A T P_{T O T A L}-A T P_{F R E E}
$$

Measurements were performed by mixing $100 \mu \mathrm{L}$ of the seawater sample and $100 \mu \mathrm{L}$ of ATP reagent in an Eppendorf tube. The mixture was agitated in an orbital mixer for 3 min at room temperature, and after $30 \mathrm{~s}$ the luminescence signal was recorded and measured as relative light units (RLU). RLU were converted to ng ATP $\mathrm{L}^{-1}$ using ATP standard dilutions (A3377, Sigma-Aldrich, USA). All the ATP analyses were performed in triplicate.

\section{Turbidity}

Turbidity was measured using a 2100P Turbidimeter (Hach, USA), in accordance with the EPA 180.1 method.

\section{Scanning electron microscopy (SEM)}

SEM images were taken of the colonized and virgin bed media. The media were fixed in $2.5 \%(\mathrm{~W} / \mathrm{W})$ of glutaraldehyde (buffered with filtered seawater at $4^{\circ} \mathrm{C}$ ) for one hour and then washed to remove residual salt. One per cent of $\mathrm{OsO}_{4}$ in filtered seawater was then used for post-fixation of the sample. Next, dehydration was carried out by rinsing with ethanol/water, followed by critical point drying with liquid $\mathrm{CO}_{2}$. Finally, the samples were sputter-coated with gold before examination with an SEM microscope (Quanta 200 FEI, XTE 325/D8395) operated at $20 \mathrm{kV}$.

\section{Fluorescence in situ hybridization (FISH)}

The presence of bacteria on the media was proved by fluorescence in situ hybridization (FISH). Thus, biomass from the backwashing was collected and fixed with 4\% paraformaldehyde (Amann et al., 1990). The oligonucleotide probe EUB338 was used to detect the bacteria domain. Additional details are available at probeBase 
(Loy et al., 2007). Hybridization was performed at $46^{\circ} \mathrm{C}$ for 90 min. EUB338 was 5' labelled with the dye FLUOS and compared with DAPI staining which is highly specific of RNA and has also been used to detect microorganisms in seawater sediments (Llobet-Brossa et al., 1998). Fluorescence signals were recorded with a confocal microscope (Leica TCS-SPE).

\section{Results and Discussion}

\subsection{SEM and FISH results}

Figure $2 \mathrm{a}$ and $2 \mathrm{~b}$ show SEM images of the virgin and colonized filter media, Biolite ${ }^{\circledR}$ L2.7, which provides porosity with voids and recesses sheltered from fluid shear forces. Thus, the biofilm can start to grow and develop, as shown in the fully colonized media. There are clear differences between the colonized and noncolonized media due to the presence of extracellular polymeric substances that are mainly composed of polysaccharides, but also proteins (Flemming and Wingender, 2001). Furthermore, the overlap of images after DAPI staining (Figures 2c) and bacteria domain (Figure 2d) obtained by FISH analysis proved the presence of bacteria populations corresponding to the bacterial domain.

\section{Figure 2}

\subsection{ATP and turbidity evolution during normal biofiltration}

Analyses of the free and total ATP were performed at the inlet stream of the biofilter and the outlet streams of columns C-1 and C-2. The ATP concentrations obtained show that some biological activity was retained during the biofiltration process (see 3a). In this work, ATP removals of $45 \%$ to $60 \%$ were achieved, depending on the biofiltration conditions. Moreover, the reduction in ATP achieved by column C-1 represented $\sim 80 \%$ of the overall removal achieved by the entire biofilter. At least 78 $80 \%$ of the ATP found in seawater is cellular ATP. Throughout the biofiltration process, depending on the conditions applied, cellular ATP represented $73-82 \%$ of the total ATP. These results indicate that in general both cellular and extracellular ATP are equally retained by the biofilter. However, despite the above mention, some ATP detached from the biofilter could be found in the biofilter effluent and then slightly decrease the retention efficiency. 
These findings agree with the bacterial reductions found by Persson et al. (2006), although we measured biological activity instead of the number of bacterial populations, and they are also in line with Meesters (2003), who found 30- to 40-fold lower ATP concentrations in biofiltered water than in feed water.

Figure $3 b$ shows the turbidity measured at the inlet and outlet streams of columns C-1 and C-2 in biofiltration processes Exp-1, Exp-2 and Exp-3 (see Table 5). The turbidity measured in the inlet streams is always low (around 1 NTU) and the turbidity in the final output streams reaches values of between 0.41 and $0.26 \mathrm{NTU}$, depending on the experimental conditions.

\section{Figure 3}

Removal of turbidity and cellular ATP compared to the EBCT by columns C-1 and C$1+\mathrm{C}-2$ is shown in Figure 4. Both turbidity and ATP follow the same pattern. More than $30 \%$ of cellular ATP is removed in an EBCT of less than 2 min. Increasing the EBCT has a positive effect on ATP removal, with 14 min of biofiltration achieving removals of around $60 \%$. Turbidity removals of about $40 \%$ are reached at an EBCT of 2 min. Finally, a maximum turbidity removal of up to $75 \%$ was also obtained with the highest EBCT of $14 \mathrm{~min}$. These reductions in turbidity are comparable with those obtained by others (Ahmad and Amirtharajah, 1998; Persson et al., 2005; Chinu et al., 2009). On the contrary, no correlation was found between these reductions and the HLR in the studied range of $6-25 \mathrm{~m} \mathrm{~h}^{-1}$.

\section{Figure 4}

\subsection{ATP and colloidal material balance}

A general mass balance is described by Equation 2. ATP and the colloidal material that gives turbidity were balanced between two consecutive backwashing processes for the different biofiltration conditions. The ATP or turbidity balance may be useful for assessing the ATP or turbidity trapped during the biofiltration process (referred to as $I-O$ in Equation 2) and generated in the biofilter due to biological activity (referred as $G$ ). The ATP and turbidity accumulated due to biofiltration but also 
generated between two consecutive backwashings in the biofilter can be determined as $E$ in Equation [2].

Assuming that backwashings were performed in the same way every time, biofiltration is considered a cyclic process in which the ATP and turbidity at the outlet of the biofilter are restored after few time of performing the backwashing.

$$
(I-O)+G=E
$$

$I=$ Input of total ATP and turbidity in seawater influent between 2 consecutive backwashings

$O=$ Output of total ATP and turbidity in BF effluent between 2 consecutive backwashings

$G=$ Generation of total ATP and turbidity into the biofilter between 2 consecutive backwashings

$E=$ Extracted ATP and colloidal material during the backwashing

The ATP and turbidity computed in the global balance in the biofiltration processes Exp-1, Exp-2 and Exp-3 are shown in Table 5. The Input and Output refer to the concentrations in the inlet and outlet streams multiplied by the total volume of seawater treated between two consecutive backwashings. Extracted ATP and turbidity were calculated as the product of the concentration estimated by the backwashing samples $\left(S_{1}, S_{2}\right.$, and $S_{3}$, see Section 2.1) and the volume of rinsing water used in the backwashing. The Generated value was calculated using Equation [2].

\section{Table 5}

These balances highlight that the generation of ATP and turbidity is much higher than the ATP and turbidity retained during the biofiltration operation $(\mathrm{I}-\mathrm{O})$. Therefore, ATP and colloidal material trapped by the biofiltration process is much lower than that which is detached during the backwashing process despite that some material from the biofilter are probably detached between the backwashings.

No direct correlation was found between the total quantity of filtered water and the quantity of ATP detached during the backwashing process $\left(\mathrm{R}^{2}=0.20\right)$. However, a direct correlation was found between the quantity of filtered water and the turbidity detached during the backwashing $\left(\mathrm{R}^{2}=0.96\right)$. A possible explanation for this finding is that the HLR is greater when the amount of filtered water is greater, and therefore 
the attrition generated in the bed medium increases. From this, we deduce that backwashing is basically an instrument for removing generated rather than trapped material.

The contribution of ATP and turbidity detached from columns C-1 and C-2 during the backwashing are shown in Figure 5. As stated before, column C-1 always contains much more ATP and colloidal material than C-2, which is in agreement with the scientific literature (Servais et al., 1994; Persson et al., 2005). Thus, a minimum of $80 \%$ of the ATP and $70 \%$ of turbidity is found in column C-1. The distribution of ATP along the biofilter depends on the filtration conditions. Decreasing the EBCT involves the shift of ATP from the input to the output of the filter, or in other words, biological activity displacement from column C-1 to C-2.

\section{Figure 5}

The measured percentages of $\mathrm{ATP}_{\mathrm{CELL}}$ in the backwashing waters are shown in Table 6. This percentage of $\mathrm{ATP}_{\mathrm{CELL}}$ was always higher than that measured in the inlet seawater. Notice that the cellular ATP of the last water sample from the backwashing $\left(\mathrm{S}_{3}\right)$, is close to the raw seawater which is used as rinsing water. As expected, the results indicate that the active biomass in the biofilter generates cellular ATP. A comparable percentage of $\mathrm{ATP}_{\mathrm{CELL}}$ was found in the first and second backwashing samples ( $S_{1}$ and $S_{2}$, respectively) for both columns and irrespective the experiment. On the contrary, the maximum turbidity was found in the first cycle (data not shown). A possible explanation for this could lie in the biological and non-biological nature of ATP and turbidity that makes bacteria to adhere to the bed medium more than colloidal particles (Ahmad and Amirtharajah, 1998).

\section{Table 6}

\subsection{Cellular ATP and turbidity correlations}

All ATP and turbidity results obtained in normal biofiltration and backwashing processes have been plotted in Figure. The possible correlations between ATP and turbidity may be interesting from an industrial control point of view (turbidity is a straightforward measure). 


\section{Figure 6}

The results show a low correlation $\left(\mathrm{R}^{2}=0.39-0.65\right)$ between these parameters, regardless of the concentration range. These findings are in line with those reported by Ahmad (1998); once again proving that turbidity is not always a good measure of cell concentration.

\section{Conclusions}

- The ATP $\mathrm{AELL}_{\mathrm{C}}$ removal by biofiltration reaches $60 \%$ at $\mathrm{EBCT}=15 \mathrm{~min}$. Furthermore, EBCT impacts positively but not the HLR in the conditions studied.

- Around $80 \%$ of the biofilter activity and colloidal material is concentrated in the first half of the biofilter.

- ATP generated between consecutive backwashings is by far higher than the biological activity retained due to biofiltration. Moreover, ATP generated in the is slightly dependent on EBCT and HLR in the range of the conditions studied. However, decreasing the EBCT implies an increase in the active volume occupied by the microorganisms in the biofilter.

- Biological and non-biological particles exhibited different trapping behaviour due to their nature.

\section{Acknowledgements}

The authors are grateful to the Spanish Ministry of Industry (CDTI) for their financial support within the framework of the Project CENIT: CEN20071039 and also to S. Lopez from the University of Barcelona and M. Abad and Dr. E. Berdalet from CMIMA-CSIC for their kind assistance.

\section{References}

Ahmad, R. and Amirtharajah, A. (1998) Detachment of particles during biofilter backwashing. Journal - American Water Works Association 90 (12), 74-85. 
Ahmad, R., Amirtharajah, A., Al Shawwa, A., Huck, P. (1998) Effects of backwashing on biological filters. Journal - American Water Works Association 90 (12), 62-73.

Amann, R. I., Binder, B. J., Olson, R. J., Chisholm, S. W., Devereux, R., Binder, B. J., Olson, R. J., Chisholm, S. W., Stahl, D. A. (1990) Combination of 16S rRNAtargeted oligonucleotide probes with flow cytometry for analyzing mixed microbial populations. Appl. Environ. Microbiol. 56 (6), 1919-1925.

Amirtharajah, A. (1993) Optimum backwashing of filters with air scour - A review. Water Science and Technology 27 (10), 195-211.

Carlson, K. H. and Amy, G. L. (1997) The formation of filter-removable biodegradable organic matter during ozonation. Ozone: science engineering 19 (2), 179-199.

Chinu, K. H., Johir, A. H., Vigneswaran, S., Shon, H. K., Kandasamy, J. (2009) Biofilter as pretreatment to membrane based desalination: Evaluation in terms of fouling index. Desalination 247 (1-3), 77-84.

Cohen, Y. (2001) Biofiltration-the treatment of fluids by microorganisms immobilized into the filter bedding material: a review. Bioresour. Technol. 77 (3), 257-274.

Deininger, R. and Lee, J. (2001) Rapid determination of bacteria in drinking water using an ATP assay. Field analytical chemistry and technology 5 (4), 185-189. 
Delahaye, E., Welte, B., Levi, Y., Leblon, G., Montiel, A., Welt, B. (2003) An ATPbased method for monitoring the microbiological drinking water quality in a distribution network. Water Res. 37 (15), 3689-3696.

Emelko, M., Huck, P., Coffey, B., Smith, E. F. (2006) Effects of media, backwash, and temperature on full scale biological filtration. Journal - American Water Works Association 98 (12), 61-73.

Flemming, H. and Wingender, J. (2001) Relevance of microbial extracellular polymeric substances (EPSs)--Part I: Structural and ecological aspects. Water Science and Technology 43 (6), 1-8.

Hammes, F., Goldschmidt, F., Vital, M., Wang, Y., Egli, T. (2010) Measurement and interpretation of microbial adenosine tri-phosphate (ATP) in aquatic environments. Water Res. 44 (13), 3915-3923.

Holm-Hansen, O. and Booth, C. R. (1966) Measurement of adenosine triphosphate in ocean and its ecological significance<br />. Limnol. Oceanogr. 11 (4), 510.

Huck, P., Zhang, S., Price, M. (1994) BOM removal during biological treatment: A first-order model. Journal - American Water Works Association 86 (6), 61-71.

Karl, D. M. (1980) Cellular nucleotide measurements and applications in microbial ecology. Microbiol. Rev. 44 (4), 739-796.

Liu, X., Huck, P., Slawson, R. (2001) Factors affecting drinking water biofiltration. Journal - American Water Works Association 93 (12), 90-101. 
Llobet-Brossa, E., Rossello-Mora, R., Amann, R. (1998) Microbial community composition of Wadden Sea sediments as revealed by fluorescence in situ hybridization. Appl. Environ. Microbiol. 64 (7), 2691-2696.

Loy, A., Maixner, F., Wagner, M., Horn, M. (2007) probeBase-an online resource for rRNA-targeted oligonucleotide probes: new features 2007. Nucleic Acids Res. 35 (Database issue), D800-D804.

Magic Knezev, A. and van der Kooij, D. (2004) Optimisation and significance of ATP analysis for measuring active biomass in granular activated carbon filters used in water treatment. Water Res. 38 (18), 3971-3979.

Meesters, K. P. H., Van Groenestijn, J., Gerritse, J., Van Groenestijn, J. W. (2003) Biofouling reduction in recirculating cooling systems through biofiltration of process water. Water Res. 37 (3), 525-532.

Miltner, R., Summers, R. S., Wang, J. (1995) Biofiltration performance: Part 2. Effect of backwashing. Journal - American Water Works Association 87 (12), 64-70.

Penru, Y., Simon, F. X., Guastalli, A. R., Esplugas, S., Llorens, J., Baig, S. (2013)

Characterization of natural organic matter from Mediterranean coastal seawater. Journal of Water Supply Research and Technology-Aqua 62 (1), 42-51.

Persson, F., Heinicke, G., Uhl, W., Hedberg, T., Hermansson, M. (2006) Performance of direct biofiltration of surface water for reduction of biodegradable organic matter and biofilm formation potential. Environ. Technol. 27 (9), 1037-1045.

Persson, F., Langmark, J., Heinicke, G., Hedberg, T., Tobiason, J., Lngmark, J., Heinicke, G., Hedberg, T., Tobiason, J., Stenstrm, T., Hermansson, M. (2005) 
Characterisation of the behaviour of particles in biofilters for pre-treatment of drinking water. Water Res. 39 (16), 3791-3800.

Servais, P., Billen, G., Bouillot, P. (1994) Biological colonization of granular activated carbon filters in drinking-water treatment. J. Environ. Eng. 120 (4), 888899.

Simon, F. X., Penru, Y., Guastalli, A. R., Llorens, J., Baig, S. (2011) Improvement of the analysis of the biochemical oxygen demand (BOD) of Mediterranean seawater by seeding control. Talanta 85 (1), 527-532.

Simon, F. X., Rudé, E., Llorens, J., Baig, S. (2013) Study on the removal of biodegradable NOM from seawater using biofiltration. Desalination 316 (0), 8-16.

Urfer, D., Huck, P., Booth, S., Coffey, B. (1997) Biological filtration for BOM and particle removal: a critical review. Journal - American Water Works Association 89 (12), 83-98.

Velten, S., Hammes, F., Boller, M., Egli, T. (2007) Rapid and direct estimation of active biomass on granular activated carbon through adenosine tri-phosphate (ATP) determination. Water Res. 41 (9), 1973-1983.

Veza, J. M., Ortiz, M., Sadhwani, J. J., Gonzalez, J. E., Santana, F. J. (2008)

Measurement of biofouling in seawater: some practical tests. Desalination 220 (1-3), 326.

Visvanathan, C., Boonthanon, N., Sathasivan, A., Jegatheesan, V. (2003) Pretreatment of seawater for biodegradable organic content removal using membrane bioreactor. Desalination 153 (1-3), 133-140. 
Wang, J., Summers, R. S., Miltner, R. (1995) Biofiltration performance: Part 1.

Relationship to biomass. Journal - American Water Works Association 87 (12), 55-

63.

Yang, L., Chou, L., Shieh, W. K. (2001) Biofilter treatment of aquaculture water for reuse applications. Water Res. 35 (13), 3097-3108. 


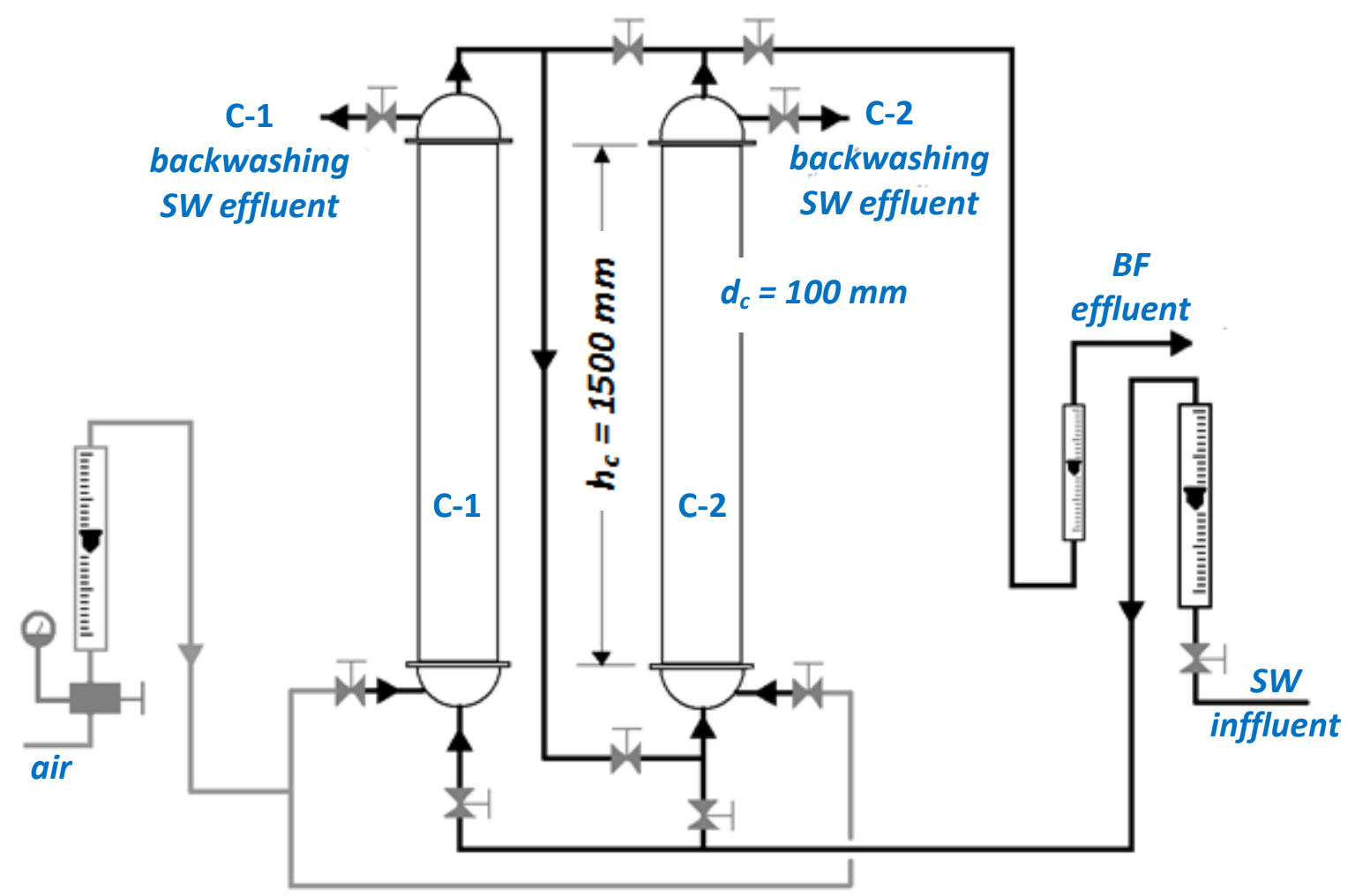

Figure 3. Schematic representation of the biofiltration facility 

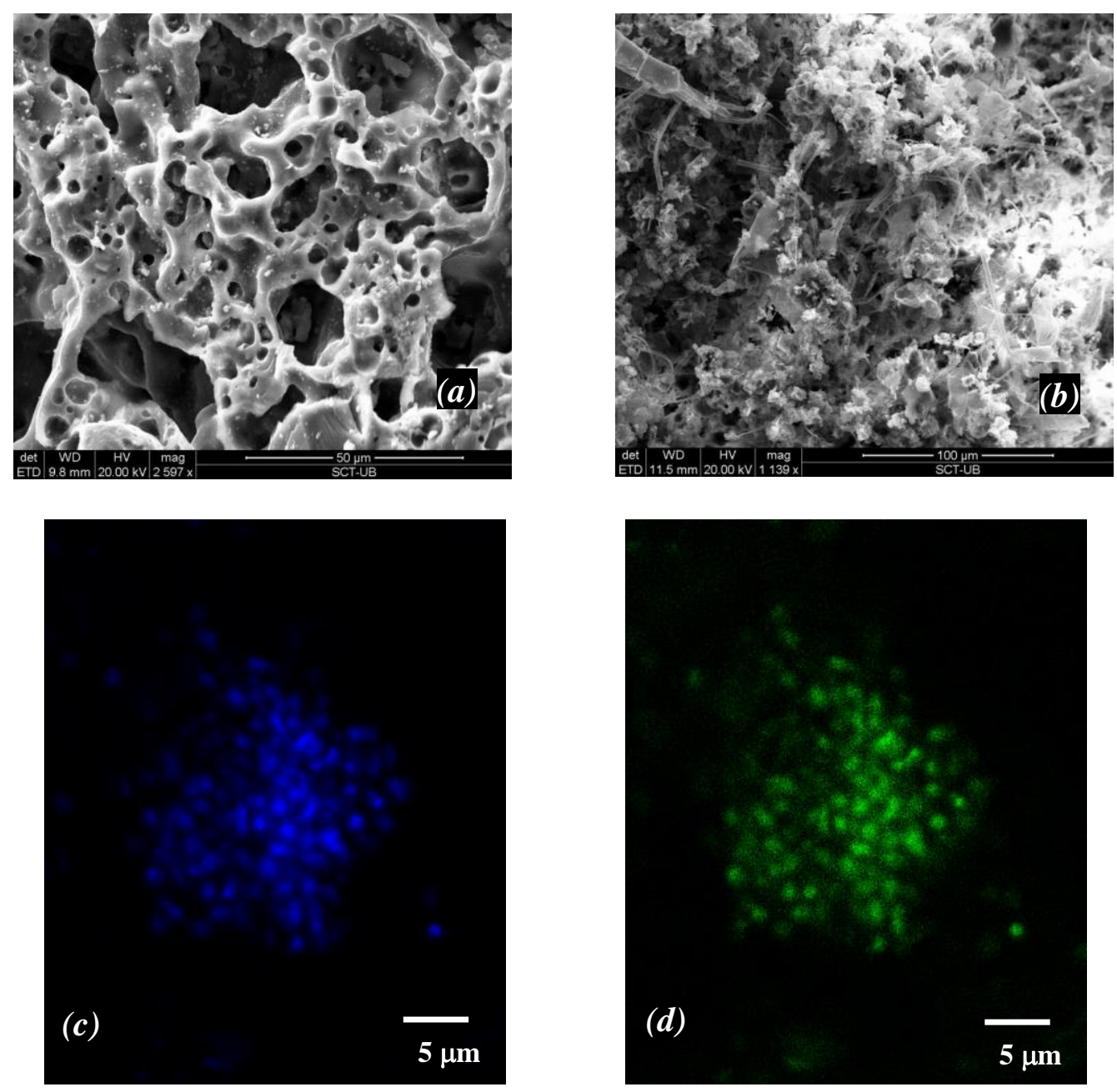

Figure 4. (a) SEM micrograph of virgin media; $(b)$ colonized media; (c) confocal micrograph after DAPI staining $(d)$ confocal micrograph of bacteria domain after labelling with EUB338 FISH probe 


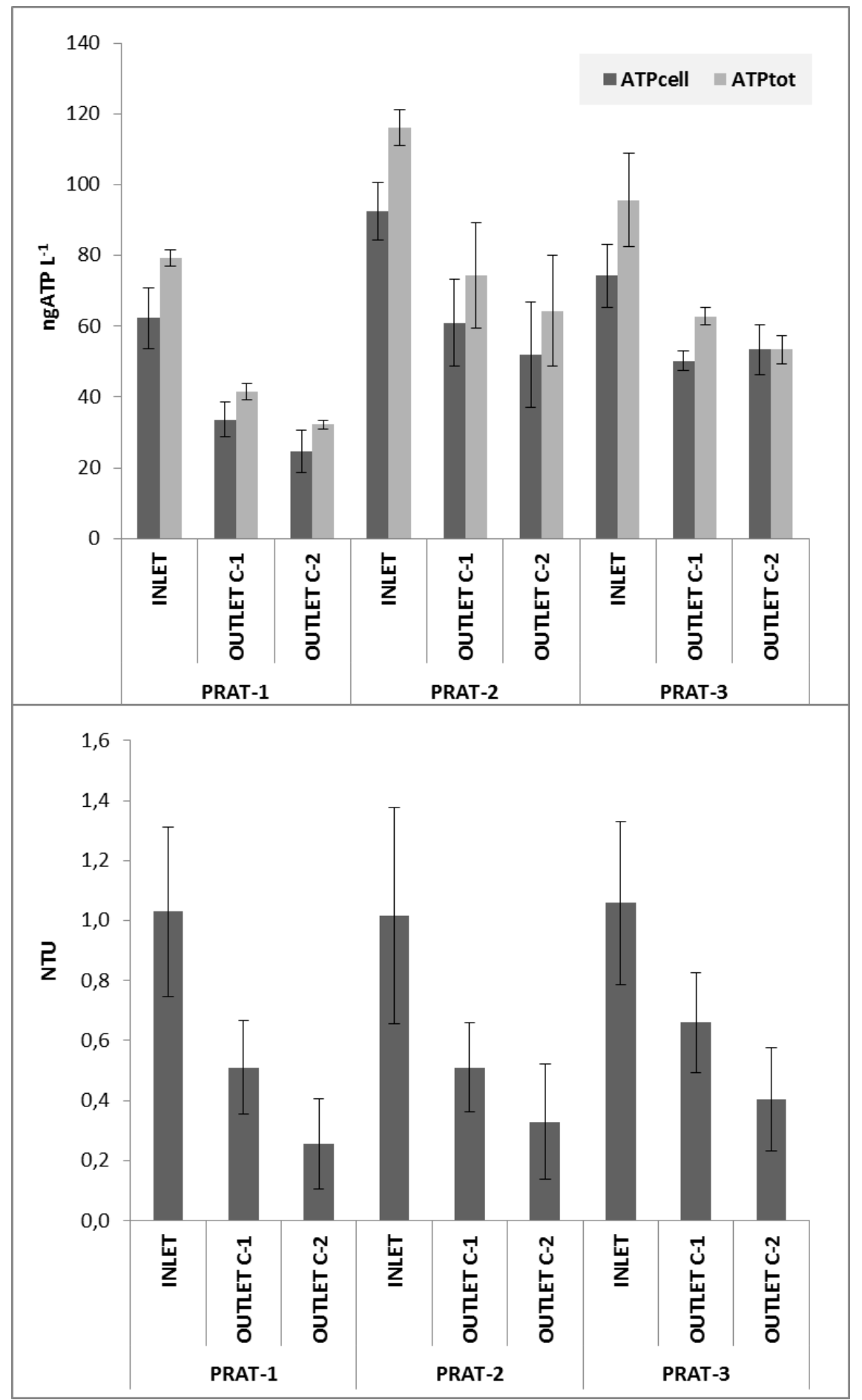

Figure 3. (a) Concentrations of $\mathrm{ATP}_{\mathrm{CELL}}$ and $\mathrm{ATP}_{\mathrm{TOTAL}}$ and (b) turbidity in the inlet stream and outlet streams of columns C-1 and C-2 in biofiltration process: Exp - 1, Exp - 2, and Exp - 3 (see Table 4).

(vertical bars correspond to std. dev.) 


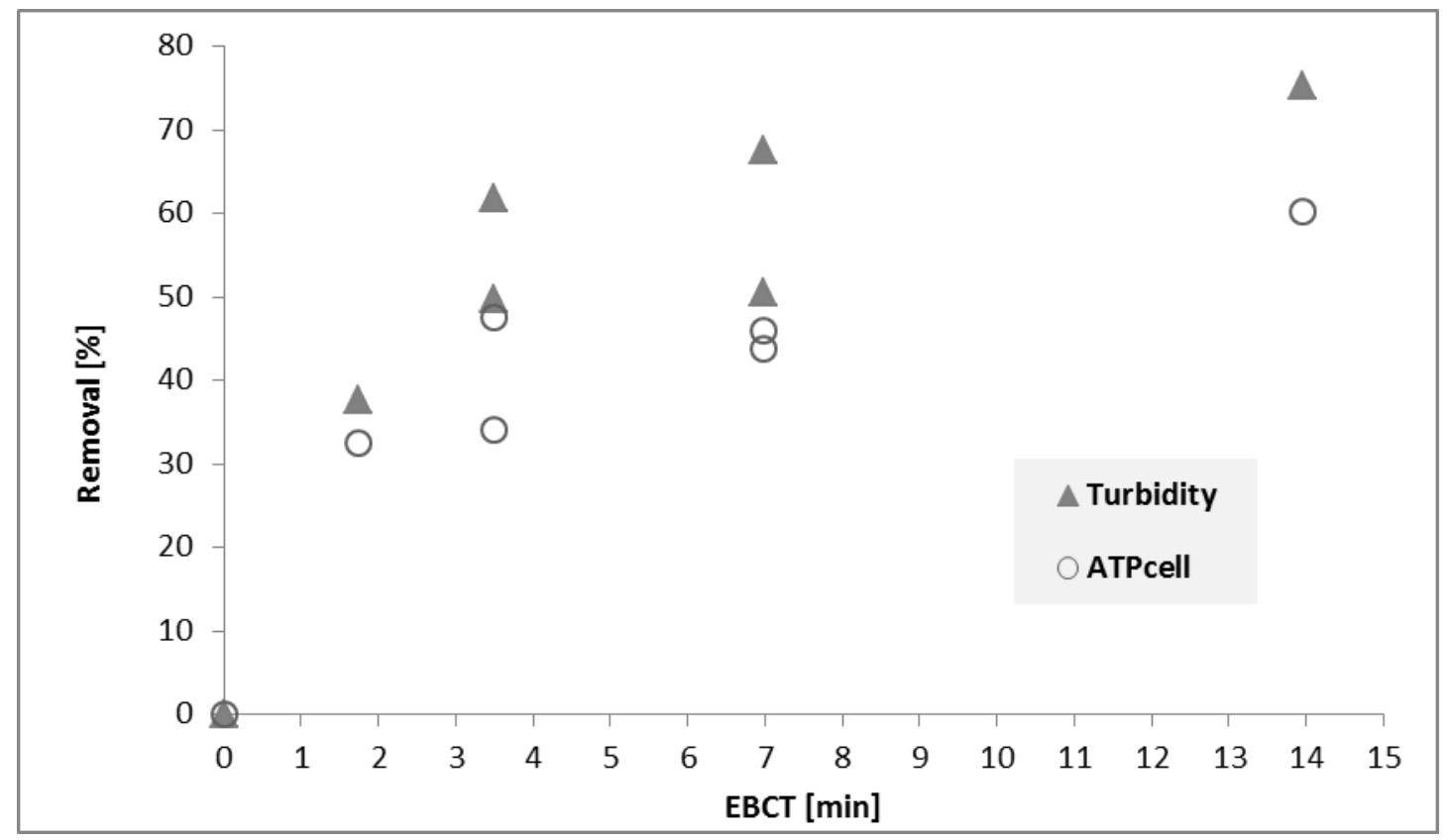

Figure 4. Removals of turbidity and $\mathrm{ATP}_{\mathrm{CELL}}$ vs. EBCT 


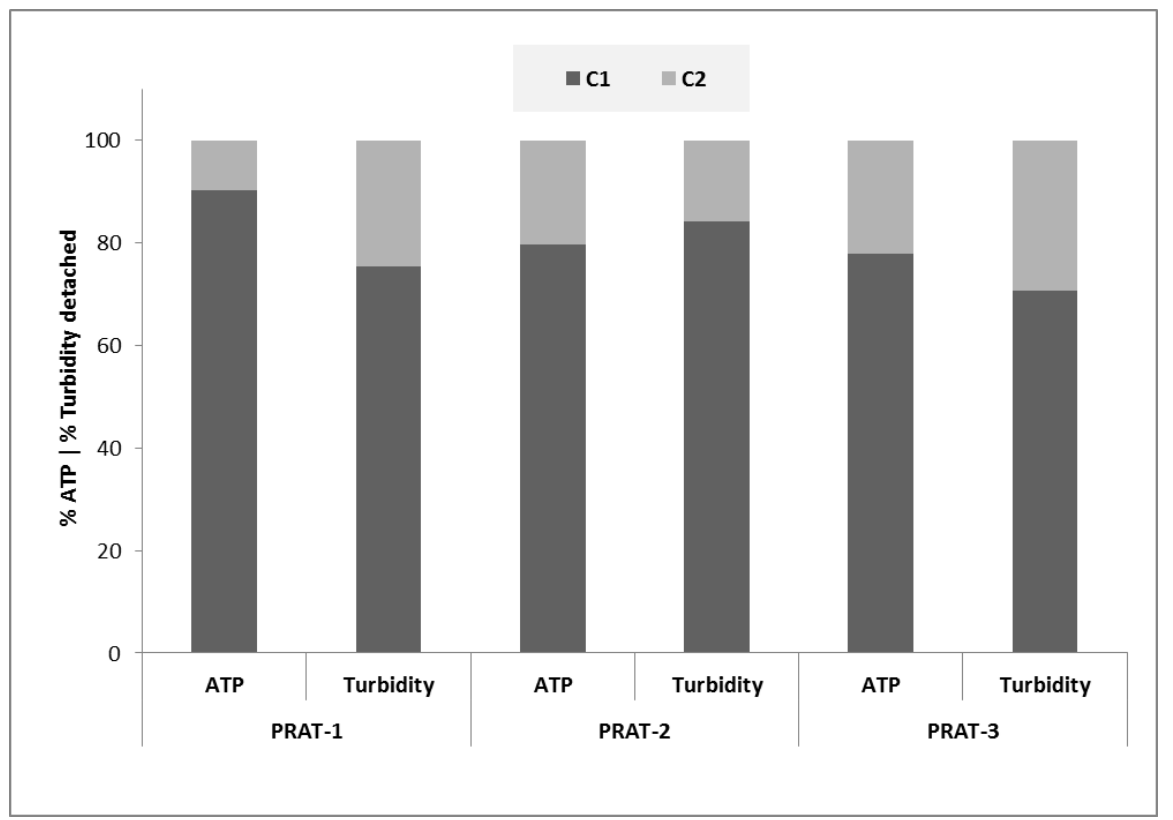

Figure 5. Relative percentage of ATP and turbidity detached in columns C-1 and C-2 during the backwashings. (Note that $\% \mathrm{C}-1+\% \mathrm{C}-2=100 \%$ ) 



Figure 6. Correlations of $\mathrm{ATP}_{\mathrm{CELL}} v s$. turbidity: $(a)$ biofiltration process; (b) backwashing process. 
Table 2. Literature on seawater biofiltration

\begin{tabular}{|c|c|c|c|c|}
\hline \multicolumn{2}{|c|}{ Biofiltration conditions } & Seawater quality & Main results & Reference \\
\hline GAC & $\begin{array}{c}\mathrm{EBCT}=60-15 \mathrm{~min} \\
\mathrm{HLR}=\text { n.d. }\end{array}$ & $\begin{array}{l}-\mathrm{DOC}^{*}=3-15 \mathrm{mg} \mathrm{L}^{-1} \\
{ }^{*} \text { modified by artificial additions } \\
\text { of sodium acetate }\end{array}$ & $\begin{array}{l}-\sim 100 \% \text { removal of biodegradable DOC } \\
\text { - Biofiltration }+ \text { MF prior to RO improved } 300 \% \text { RO permeate flux }\end{array}$ & Visvanathan et al., 2003 \\
\hline $\begin{array}{c}\text { GAC } \\
\text { anthracite }\end{array}$ & $\begin{array}{l}\mathrm{EBCT}=10-5 \mathrm{~min} \\
\mathrm{HLR}=5-10 \mathrm{~m} \mathrm{~h}^{-1}\end{array}$ & $\begin{array}{l}-\mathrm{pH}=8.10 \\
-\mathrm{Turb} .=0.5-0.7 \mathrm{NTU} \\
-\mathrm{TDS}=35 \mathrm{~g} \mathrm{~L}^{-1}\end{array}$ & $\begin{array}{l}\text { - MFI outlet }=10 \mathrm{~s} \mathrm{~L}^{-2} \text { for both biofilters } \\
\text { - Turb. }=0.2-0.3 \mathrm{NTU} \\
\text { - RO flux decline faster when no pre-treatment was provided }\end{array}$ & Chinu et al., 2009 \\
\hline GAC & $\begin{array}{l}\text { EBCT }=11-5 \mathrm{~min} \\
\mathrm{HLR}=5-10 \mathrm{~m} \mathrm{~h}^{-1}\end{array}$ & $\begin{array}{l}-\mathrm{pH}=8.03 \\
\text { - Turb. }=0.68 \\
\text { - Conduct. }=39.9 \mathrm{mS} \mathrm{cm}{ }^{-1} \\
\text { - } \text { DOC }=1.85 \mathrm{mg} \mathrm{L}^{-1}\end{array}$ & $\begin{array}{l}\text { - DOC removal }>60 \% \text { (especially LMW organics) } \\
\text { - AOC outlet }=0.6 \mu \mathrm{g}-\mathrm{C} \mathrm{L}^{-1} \\
\text { - TEP outlet }=5.3 \mu \mathrm{g}-\mathrm{C} \mathrm{L}^{-1}\end{array}$ & Naidu et al., 2013 \\
\hline EC & $\begin{array}{l}\mathrm{EBCT}=11-6 \mathrm{~min} \\
\mathrm{HLR}=5-10 \mathrm{~m} \mathrm{~h}^{-1}\end{array}$ & $\begin{array}{l}-\mathrm{DOC}=0.96 \mathrm{mg} \mathrm{L}^{-1} \\
-\mathrm{BOD}_{7}=1.11 \mathrm{mg} \mathrm{L}^{-1} \\
-\mathrm{A}_{254}=0.67 \mathrm{~m}^{-1} \\
- \text { Turb. }=1.06 \mathrm{NTU}\end{array}$ & $\begin{array}{l}- \text { DOC removal }=6 \%(\text { LMW neutrals } 33 \% \text { and biopolymers } 17 \%) \\
-\mathrm{BOD}_{7} \text { removal }=15 \% \\
-\mathrm{ATP} \text { removal }=60 \% \\
-94 \% \text { of biofilm formation capacity reduction }\end{array}$ & Simon et al., 2013 \\
\hline
\end{tabular}

$\mathrm{A}_{254}=$ Absorbance at $\lambda=254 \mathrm{~nm} ; \mathrm{ATP}=$ Adenosine triphosphate; $\mathrm{BOD}_{7}=$ Biochemical oxygen demand at 7 days $;$ Conduct. $=$ Conductivity; DOC $=$ Dissolved organic carbon; EBCT $=$ Empty bed contact time; $\mathrm{EC}=$ Expanded clay; GAC $=$ Granulated activated carbon; HLR = Hydraulic loading rate; LMW = Low molecular weight; MF = Microfiltration; MFI = Modified fouling index; RO = Reverse osmosis; TEP = Transparent exopolymer particles; TDS = Total dissolved solids; Turb. = Turbidity;. . = no data. 
Table 3. Features of the packed bed

\begin{tabular}{rcc}
\hline Parameter $^{*}$ & Units & Value \\
\hline Height of the bed & $\mathrm{cm}$ & 75 \\
Diameter of the bed & $\mathrm{cm}$ & 10 \\
Ratio height/diameter & - & 7.5 \\
Bed volume & $\mathrm{L}$ & 6 \\
Porosity & - & 0.4 \\
Interfacial area & $\mathrm{m}^{-1}$ & 1333 \\
Bulk density & $\mathrm{kg} \mathrm{m}^{-3}$ & $730-900$ \\
\hline
\end{tabular}

*Both columns (C-1 and C-2) have the same characteristics 
Table 3. Seawater quality

\begin{tabular}{ccc}
\hline Parameter & Units & Value \\
\hline $\mathrm{pH}$ & - & 8.2 \\
Tubidity & $\mathrm{NTU}$ & $1.03 \pm 0.28$ \\
$\mathrm{TDS}$ & $\mathrm{g} \mathrm{NaCl} \mathrm{L}^{-1}$ & $32.5 \pm 0.6$ \\
Conductivity & $\mathrm{mS} \mathrm{cm}^{-1}$ & $57.4 \pm 0.4$ \\
$\mathrm{BOD}_{7}$ & $\mathrm{mg} \mathrm{O}_{2} \mathrm{~L}^{-1}$ & $1.57 \pm 0.56$ \\
$\mathrm{DOC}$ & $\mathrm{mg} \mathrm{C} \mathrm{L}^{-1}$ & $0.78 \pm 0.10$ \\
$\mathrm{~A}_{254}$ & $\mathrm{~m}^{-1}$ & $0.56 \pm 0.06$ \\
$\mathrm{Algae}$ & $\mathrm{cells} \mathrm{mL}^{-1}$ & $264 \pm 120$ \\
$\mathrm{SDI}_{15}$ & $\% \mathrm{~min}^{-1}$ & $7.5 \pm 6.2$ \\
$\mathrm{~T}$ & ${ }^{\circ} \mathrm{C}$ & $17 \pm 3$
\end{tabular}

TDS: Total dissolved solids; $\mathrm{BOD}_{7}$ : Biochemical Oxygen Demand at 7 days; DOC: Dissolved Organic Carbon; $\mathrm{A}_{254}$ : UV absorbance at $\lambda=254 \mathrm{~nm}$; $\mathrm{SDI}_{15}$ : Silt Density Index at $15 \mathrm{~min}$; T: Temperature 
Table 4. Operational conditions in the biofiltration process

\begin{tabular}{cccc}
\hline Name & $\begin{array}{c}\text { Flow rate } \\
{\left[\mathbf{L ~ h}^{-\mathbf{1}}\right]}\end{array}$ & $\begin{array}{c}\text { HLR } \\
{\left[\mathbf{m ~ h}^{\mathbf{- 1}}\right]}\end{array}$ & $\begin{array}{c}\text { EBCT } \\
{[\mathbf{m i n}]}\end{array}$ \\
\hline Exp - 1 & 50 & 6.4 & $7.0+7.0=14$ \\
Exp - 2 & 100 & 12.7 & $3.5+3.5=7.0$ \\
Exp - 3 & 200 & 25.5 & $1.8+1.8=3.6$ \\
\hline
\end{tabular}

${ }^{*} \mathrm{EBCT}_{\mathrm{C}-1}+\mathrm{EBCT}_{\mathrm{C}-2}=\mathrm{EBCT}_{\mathrm{BF}}$ 
Table 5. ATP ${ }_{\text {TотAL }}$ and turbidity computed in the global balance in biofiltration process: Exp - 1, Exp - 2, and Exp - 3. The Input and Output correspond to the concentrations in the inlet and outlet streams multiplied by the total volume of water treated between two consecutive backwashings. ATP and turbidity Extracted were calculated as the product of the concentration by the volume of water used in the backwashing. The Generated was calculated using Equation [2].

\begin{tabular}{|c|c|c|c|c|c|}
\hline Name & $\begin{array}{l}\text { EBCT } \\
{[\mathrm{min}]}\end{array}$ & $\begin{array}{c}\text { Treated water } \\
\qquad\left[\mathrm{L} \times \mathbf{1 0}^{-3}\right]\end{array}$ & $\begin{array}{l}\text { INPUT - OUTPUT } \\
\text { ATP }_{\text {TOTAL }}[\mu \mathrm{g} \text { ATP }] \\
\text { Turb } \times \mathbf{1 0}^{-3}[\text { NTU L }]\end{array}$ & $\begin{array}{c}\text { EXTRACTED } \\
\text { ATP }_{\text {TOTAL }}[\mu \mathrm{g} \text { ATP }] \\
\text { Turb } \times \mathbf{1 0}^{-3}[\mathrm{NTU} \mathrm{L}]\end{array}$ & $\begin{array}{c}\text { GENERATED } \\
\text { ATP }_{\text {TOTAL }}[\mu \mathrm{g} \text { ATP }] \\
\text { Turb } \times 10^{-3}[\mathrm{NTU} \mathrm{L}]\end{array}$ \\
\hline Exp - 1 & $7+7=14$ & 4.2 & $\begin{array}{l}197 \\
3.3\end{array}$ & $\begin{array}{c}6460 \\
368\end{array}$ & $\begin{array}{c}6262 \\
364\end{array}$ \\
\hline Exp - 2 & $3.5+3.5=7$ & 8.4 & $\begin{array}{l}435 \\
5.4\end{array}$ & $\begin{array}{l}5559 \\
1007\end{array}$ & $\begin{array}{l}5123 \\
1002\end{array}$ \\
\hline Exp - 3 & $1.8+1.8=3.6$ & 17 & $\begin{array}{c}709 \\
11.0\end{array}$ & $\begin{array}{l}7421 \\
1635\end{array}$ & $\begin{array}{l}6712 \\
1624\end{array}$ \\
\hline
\end{tabular}


Table 6. Percentage of $\mathrm{ATP}_{\mathrm{CELL}}$ in the backwashing water samples (more information regarding water samples: S1, S2, and S3 can be found in

\begin{tabular}{|c|c|c|c|c|c|c|}
\hline \multirow{3}{*}{ Name } & \multicolumn{3}{|c|}{ Section 2.1 } & \multicolumn{3}{|c|}{ 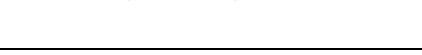 } \\
\hline & & $\mathbf{T P}_{\mathbf{C}}$ & & & $\mathbf{P}_{\text {CEI }}$ & \\
\hline & $\mathbf{S}_{1}$ & $\mathbf{S}_{2}$ & $\mathbf{S}_{\mathbf{3}}$ & $\mathbf{S}_{\mathbf{1}}$ & $\mathbf{S}_{2}$ & $\mathbf{S}_{\mathbf{3}}$ \\
\hline Exp - 1 & 95 & 97 & 87 & 94 & 96 & 88 \\
\hline Exp - 2 & 95 & 97 & 83 & 95 & 96 & 83 \\
\hline Exp - 3 & 95 & 97 & 90 & 93 & 95 & 92 \\
\hline
\end{tabular}

3 